\title{
ULTRASTRUCTURE OF OVARIAN FOLLICULAR EPITHELIUM OF THE AMAZONIAN FISH Pseudotylosurus microps (TELEOSTEI: BELONIDAE): MORPHOLOGICAL AND HISTOCHEMICAL CHARACTERIZATION OF THE INTERCELLULAR DEPOSITS
}

\author{
CRUZ-LANDIM, C. ${ }^{1}$ and CRUZ-HÖFLING, M. A. ${ }^{2}$ \\ ${ }^{1}$ Departamento de Biologia, Instituto de Biociências, Unesp, CEP 13506-900, Rio Claro, SP, Brazil \\ ${ }^{2}$ Departamento de Histologia e Embriologia, Instituto de Biologia, Unicamp, CEP 13083-970, Campinas, SP, Brazil \\ Correspondence to: Carminda da Cruz-Landim, Departamento de Biologia, Instituto de Biociências, Unesp, \\ C.P. 199, CEP 13506-900, Rio Claro, SP, Brazil, e-mail: cclandim@rc.unesp.br \\ Received October 6, 1999 - Accepted April 25, 2000 - Distributed February 28, 2001
}

(With 4 figures)

\begin{abstract}
The present paper reports the presence of great quantities of electrondense intercellular material in the follicular epithelium of $P$. microps. The material apparently is uptaken from circulation and enter the follicle through the intercellular spaces accumulating in the epithelial median-apical intercellular spaces and in perioocytic space. The accumulation starts in the early growth of the primary oocyte and proceed until vitellogenesis. The possible chemical nature and function of the deposits are discussed.
\end{abstract}

Key words: chorion, oocytes, oogenesis, electrondense deposits, follicle.

\section{RESUMO}

Ultra-estrutura do epitélio folicular do ovário do peixe amazônico Pseudotylosurus microps (Teleostei: Belonidae): caracterização morfológica e histoquímica dos depósitos intercelulares

Neste trabalho é mostrada a grande quantidade de material eletrondenso intercelular no epitélio folicular de P. microps. Aparentemente, o material é captado da circulação e enviado para o folículo por meio dos espaços intercelulares, acumulando-se nos espaços intercelulares médio-apicais do epitélio e no espaço perioocítico. A acumulação é iniciada no oócito primário e prossegue até a vitelogênese. A natureza química desse material é discutida.

Palavras-chave: cório, oócitos, oogênese, depósitos eletrondensos, folículo.

\section{INTRODUCTION}

The ultrastructure of oogenesis in fishes have been studied by several authors concerning the developmental stages of oocytes growth (Anderson, 1974; Iwasaki, 1973; Bruslé, 1980; Cruz-Landim \& Cruz-Höfling, 1979; Droller \& Roth, 1966; Norrevang, 1968; Wourms, 1976; Shackley \& King, 1977), the cellular envelopes of the devel- oping oocyte (Chaudry, 1956; Cruz-Landim et al., 1987; Nicholls \& Maple, 1972; Lambert, 1970; Shelton, 1978; Cruz-Höfling \& Cruz-Landim, 1992; Hirose, 1972; Cruz-Landim, 1990; Khoo, 1975) and the oocyte acellular covers, during its growth and after egg maturation (Anderson, 1966, 1967; Busson-Mabillot, 1977; Cruz-Höfling \& Cruz-Landim, 1990; Dumont \& Brummett, 1980; Hart et al., 1984; Lopes et al., 1982; Wourms \& 
Sheldon, 1976; Tesoriero, 1978; Fleger, 1977). However although seems to have accordance among the authors about the phases of the oocyte growth and the description of the characteristic structures present in it the same do not happens concerning the egg cellular and acellular covers. In fact the structure of follicular epithelium seems to be very much variable from one group to another. In face of this it function, as well as the function of the thecal sheath is not well stablished. In the same way the acellular covers that invest the oocyte during it development and after ovulation do not have it origin and function well defineded.

These structures have, however, had a longstanding appeal to the biologists since questions as ovary steroid synthesis, and adaptation of oocytes to certains environment conditions have been attributed to the cellular and acellular coverings respectively.

This work intent to contribute to the heap of knowledge about the oocytes covers, when still in the ovary, in order to form a background to the understanding of the pendent questions. In this context, a morphological and histochemical characterization of "adorning" elements found in the interstices of the follicular epithelium was made.

\section{MATERIAL AND METHODS}

Fragments of ovaries of the telostean $P$. microps, collected in Solimões River (Amazon Basin) were fixed to optical and electron microscopic studies.

For electron microscopy the pieces were fixed in $2.5 \%$ glutaraldehyde buffered with $0.2 \mathrm{M}$ sodium caccodilate, $\mathrm{pH} 7.2$, containning $4 \%$ sucrose and post-fixed in $1 \%$ osmium tetroxide in the same buffer.

After fixation the pieces were dehydrated in increasing concentration series of ethanol and via propylene oxide, embedded in Apon-Araldite resin. Sections obtained with glass knives were doublecontrasted with uranyl acetate and lead citrate. The examination and photography were made on a Zeiss EM9S2 electron microscope.

For light microscopy the ovary fragments were fixed in $10 \%$ neutral formaldehyde and embbeded in paraffin. To the paraffin section were applied histochemical tests (see Table 1) according Pearse (1960) to show acidic and neutral muco- polyssacharids (also the sulfated ones), reducing group as $\mathrm{SH}, \mathrm{NH}$ groupments, cholesterol and elastic fibers.

\section{RESULTS}

In the course of the study of $P$. microps oogenesis our attention was driven to peculiar features of its follicular epithelium. The follicular epithelium around the oocytes between the primary phase of oocyte development and early vitellogenesis accumulate in its intercellular spaces numerous polymorphous bodies, in resin sections, stainable with toluidine blue and other acidic stains (Fig. 1). During the vitellogenic phase of the oocyte, the number and size of these structures is such that can even shade the epithelial cells to the light microscopy examen.

The origin and evolution of these material revealed to be dificult to follow, but as the ovary of $P$. microps is of asyncronous type several stages of accumulation can be seen at same time in different follicles.

\section{Ultrastructure}

An attempt of follow the evolution of the material accumulated in the intercellular space of the follicular cells was made taken in account the growth phase of the oocyte enclosed in the follicle. By this approach it can be seen that when the oocyte is in the perinucleolar phase and the follicular epithelium is still flat, the material appears only in the apical face, frequently occupying the space between the oocyte surface and the follicular cell top (perioocytic space) (Fig. 2A, B). In this stage the bodies appear made of reticular or concentric lamellae of electrondense material as in Fig. 2A or as compact electrondense masses (Fig. 2B).

In any case the amount of material accumulated is so, that the perioocytic space is enlarged and the follicular cells and oocytic surface deformed (Figs. 1 and 2).

It seems that the masses are compressed against the oocyte surface, producing an intrusion in its cytoplasm. The microvilli present in the oocyte surface, frequently disappear from these regions and there are morphological evidences that the material could enter the oocyte cytoplasm, as seen in the Figs. 1 and 2A, where the denser part of the material seems to pulverized and pass 
to the oocyte cytoplasm or as in Fig. 2B, where the electrondense mass push the oocyte surface inward.

In this phase the follicular epithelium intercellular spaces are note widened but some electrondense material may be seen fulfilling the basal portion of the cellular contacts (Fig. 2A, B).

In vitellogenic oocytes the follicular epithelium have increased very much in height and the intercellular spaces between cells appear totally occupied by polimorphous dense bodies (Figs. 1, 3 and 4).

The now electrondense bodies may appear homogeneously amorphous, and spherical, as in Fig. 3 or elongated and fibrillar, with differently structurated material aggregated to their periphery (Fig. 4A, B).

It seems that these bodies tend to coalesce and that the less dense material makes the link between them during the coalescence process. It is not ease to discerne the intercellular localization of this material because of its huge size that somewhat disorganized the epithelium. Where is possible to perceive the cellular contacts, as in basal side of the epithelium, they are closed. However even there can be seen electrondense material inside it and in connection with the dense bodies.

In this phase the oocyte has already at least two layers of vitelline envelope around it and sometimes can be seen the contacts between the dense bodies and the outer layer (still in deposition process) of this envelope (Fig. 3).
The dense bodies polymorphism may be due to different stages of their accumulation or mobilization. In fact, it can be seen, as already mentioned, the presence of less dense and organized material in the periphery of certain bodies, as well as it can be seen regions where the fibrillar arrangement is patent due both to the loose compactation of the fibrils and to the tangential section of the boundaries of them (Fig. 4A). Some granules present even paracrystalline organization being their fibrillar constituents disposed with highly regular periodicity (Fig. 4B).

The described material starts to accumulate during early perinucleolar phase of the oocyte and probably reachs their peak in early vitellogenic oocytes. However, even after the end of the oogenesis, when the mature egg have already completed the deposition of the acellular coverings, great amounts of the bodies are still present. When, after the end of the oocyte growth the follicular epithelium is disrupted the dense bodies seem remain entire.

\section{Histochemistry}

As seen in Table 1 the histochemical tests applied to the ovaries show that the material occuping the intercellular space of the follicular cells is negative to Alcian Blue, $\mathrm{pH}$ 0.5, 2.5 and Ninhidryn Schiff. It is positive to PAS and Schiff, and react strongly to ferric ferricyanide which indicates the presence of reducing groups.

The previous blokage by $\mathrm{HgCl}_{2}$ decrease the reaction intensity, which demonstrates that the

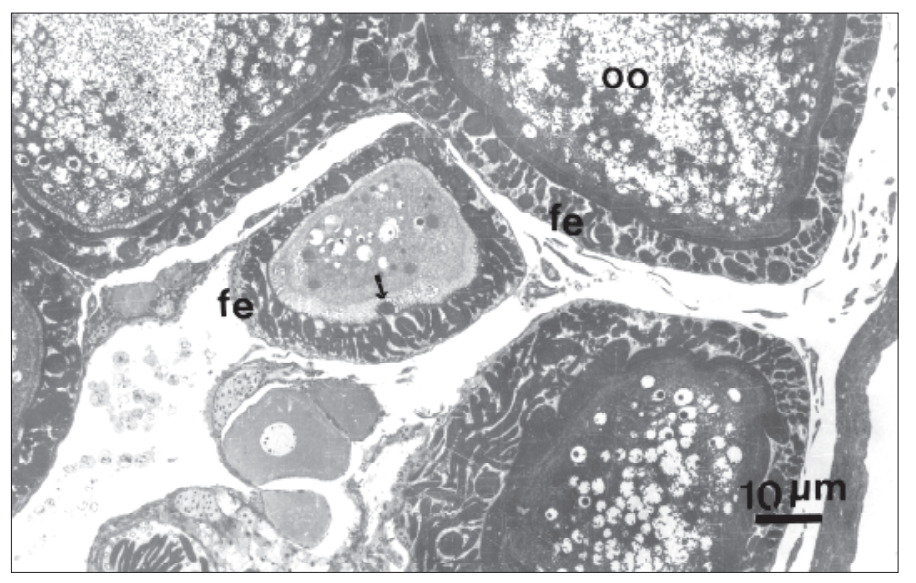

Fig. 1 - Micrograph of thick a section from material processed to electron microscopy stained with toluidine blue. Oocytes (oo) in different phases of oogenesis showing that in early oocyte development the dense material seem to enter the oocyte (arrows). fe = follicular epithelium. 

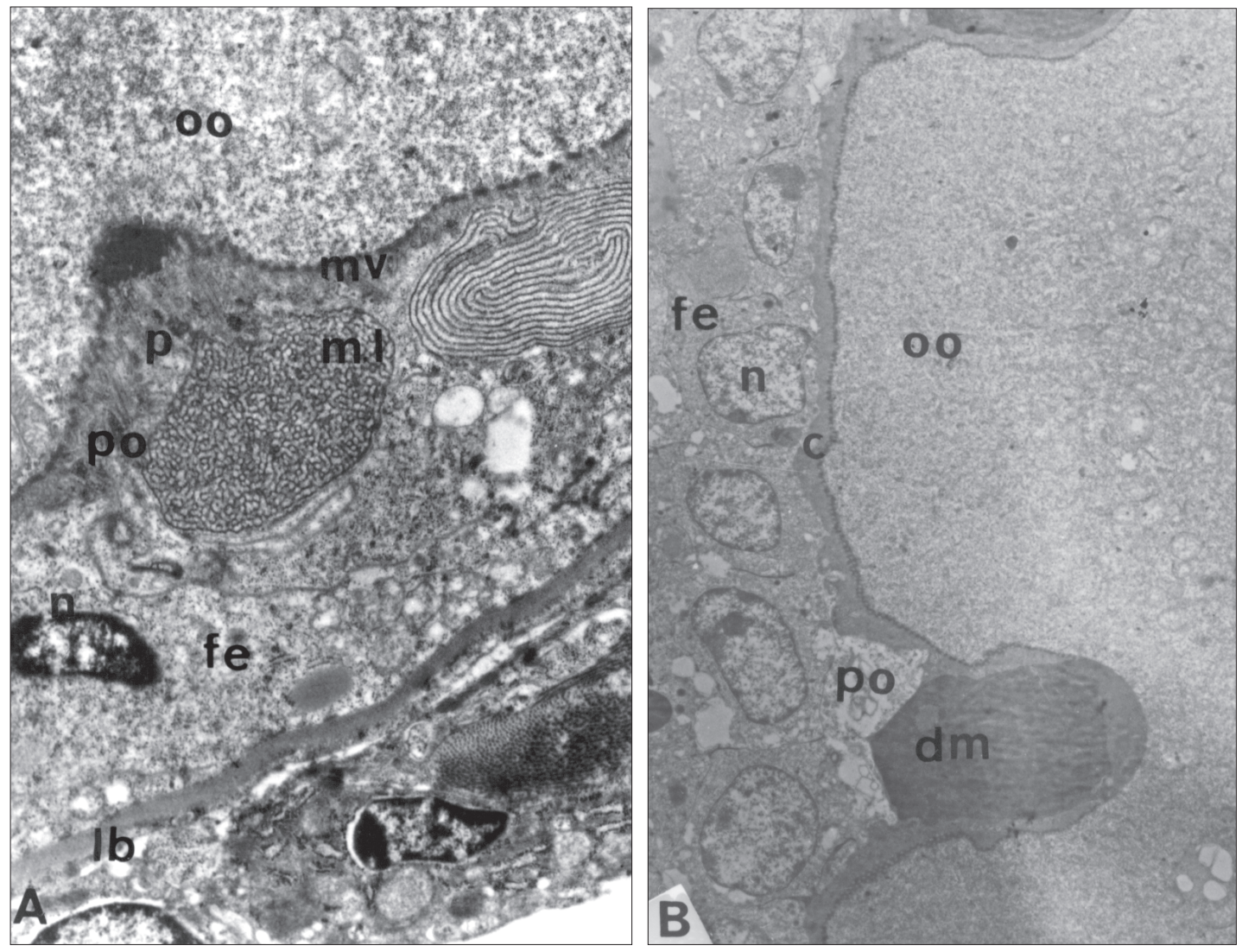

Fig. 2 - Aspects of the material present in the perioocytic (po) space of follicles in the perinucleolar stage. A. Material lamelar ( $\mathrm{ml}$ ) and powder (p) apparently being incorporated by the oocyte (oo). B. Dense material (dm) compressing the oocyte (oo) surface. $\mathrm{fe}=$ follicular epithelium; $\mathrm{po}=$ perioocytic space; $\mathrm{n}=$ nuclei; $\mathrm{c}=$ oocyte envelope; $\mathrm{mv}=$ microvilli; $\mathrm{lb}=$ basal lamina.

TABLE 1

Histochemical results.

\begin{tabular}{|l|l|c|}
\hline \multicolumn{1}{|c|}{ Reactions } & \multicolumn{1}{c|}{ Reactive groups } & Reaction intensity \\
\hline Schiff & Reductor groups & \pm \\
\hline Ninhidryn Schiff & $\mathrm{NH}_{2}$ groups & - \\
\hline PAS & Polysaccharids & + \\
\hline PAS + diastase & Acid & - \\
& Neutral & - \\
\hline PAS + sodium desoxicolate & Lipids with vic-glicol groupments & - \\
\hline Toluidin blue & Cholesterol & + \\
\hline Adams (ferric ferricianide) & Reductor groups & +++ \\
\hline Adams $+\mathrm{HgCl}_{2}$ & SH reductor groups & - \\
\hline Alcian blue $\mathrm{pH} 2.5$ & Proteoglicans & - \\
\hline Alcian blue $\mathrm{pH} 0.5$ & Sulfated proteoglicans & - \\
\hline Aldehide fucsin & Elastic fibers & - \\
\hline
\end{tabular}

- Negative reaction.

\pm Weak reaction.

+ Moderate reaction.

+++ Strong reaction. 


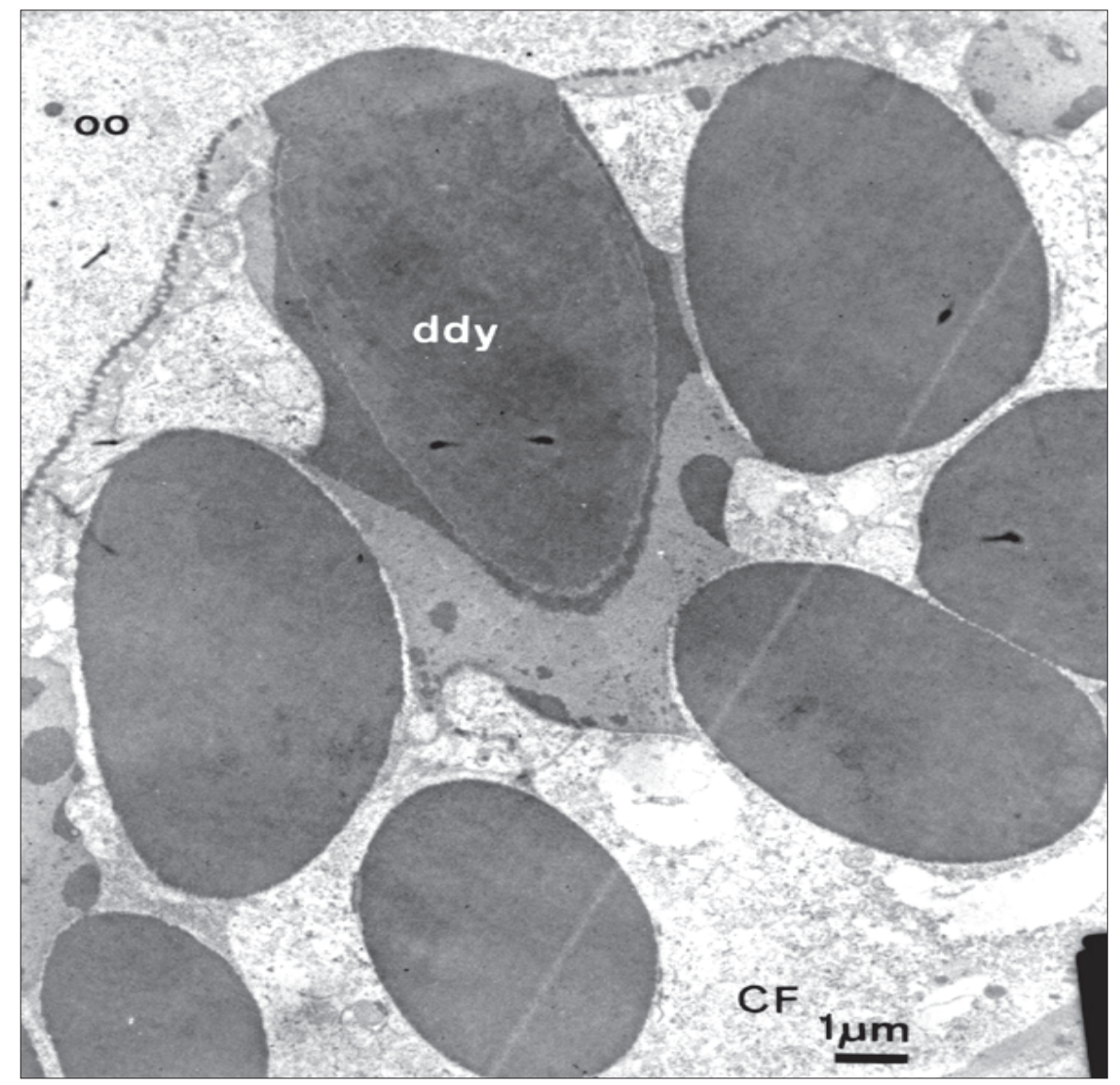

Fig. 3 - Contact between the dense material in the perioocytic space with the outer layer of the chorion. Notice the coalescence of the deposits (ddy) by the adition a new material of different electron densities. $\mathrm{CF}=$ follicular cell.

presence of SH groupments, are responsible by the positivity. Also was demonstrated the absence of elastic fibers.

\section{DISCUSSION AND CONCLUSIONS}

The electrondense deposits that acccumulate in the intercellular spaces of follicular epithelium and in the perioocytic space tend to increase as the oocyte proceed in its development. This material seems to originate from substances intaken in the basal side of the follicular epithelium and travel to the apical one. The basal intercellular space between cells remain narrow during all the process although filled with electrondense material, showing that the material must enter this space slowly and accumulate apically. It is clear that the material present in the perioocytic space reached this location coming through the intercellular space of follicular cells, since in no moment similar deposits were seen inside the follicular cells.

It is known that some or all of the oocyte yolk has an exogenous origin, probably being synthesized in liver and transported to the ovary through circulation (Bruslé, 1980; Droller \& Roth, 1966; Norrevang, 1968). The uptake of this vitellogenin material is made through the intercellular spaces of follicular cells and later by pynocitic activity on the oocyte surface. It is, therefore, possible that some of the electrondense material, mainly that one arising early in the oocyte development were of vitellogenic nature.

It is also currently known that part of the acellular envelope of oocyte is both synthesized by the oocyte and follicular epithelium (Anderson, 

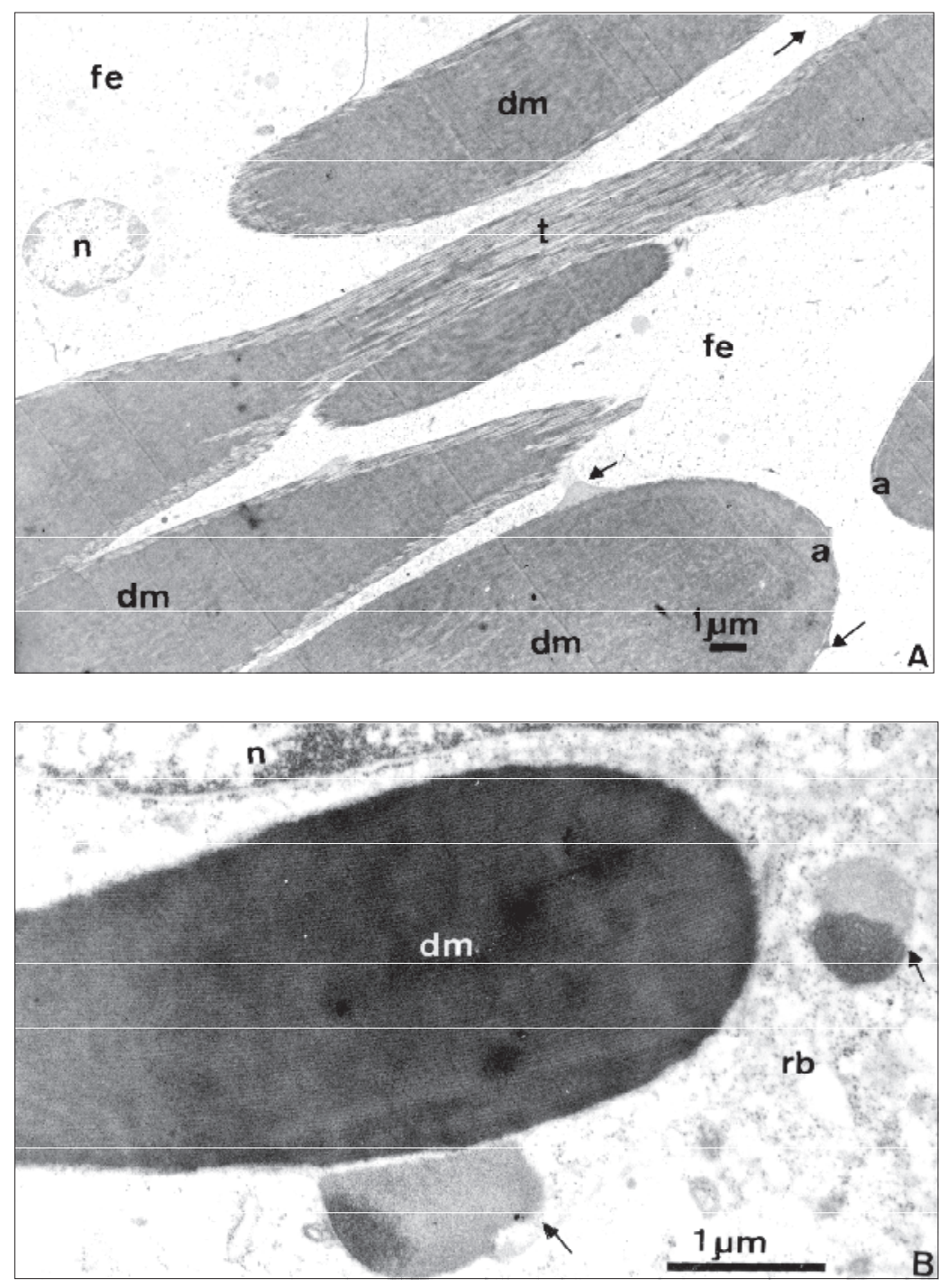

Fig. 4 - Additional aspects of the dense material $(\mathrm{dm})$. A. Fibrilar nature of the dense bodies $(\mathrm{dm})$ and the amorphous less denser periphery. The arrows point to the less dense material coming through the intercellular space. B. Paracrystalline arrangemment of the material in the big masses $(\mathrm{dm})$ and isolated less denser material (arrows). fe $=$ follicular epithelium; $\mathrm{n}=$ cell nuclei; $\mathrm{rb}=$ ribosomes; $\mathrm{a}=$ amorphous material.

1967; Chaudry, 1956; Dumont \& Brummett, 1980; Fleger, 1977; Tesoriero, 1978; Begovac \& Wallace, 1989). The responsibility more frequently appointed to this synthesis is to the follicular epithelium. However in this case there are some morphological evidence that the electrondense material can contribute to the formation of the outer envelope of the oocyte, or chorion.

The chorion, of mature teleost eggs, is a proteinaceous covering. The paracrystalline pattern assumed by some of the intercellular bodies seems to point to a proteinic nature, but the Ninhidryn Schiff reaction fail in show the presence of $\mathrm{NH}_{2}$ groupments in the material. This fail may be due to the lack of free $\mathrm{NH}_{2}$ groups. On the other hand, the presence of $\mathrm{SH}$ free radicals in this deposits are not well understood but they were already demonstrated in the chorion of marine teleosteans (Begovac \& Wallace, 1989) and in the sea urchin they are responsible by the egg activation. 
From the histochemical testes applied only polysaccharids, reductor groups and SH groups was demonstrated present in the intercellular deposits. Therefore also the histochemical results indicate that the intercellular deposits could be formed by vitellogenic or by chorionic proteins.

Whatever are the electrondense material functions, it is strange the great amounts of accumulation and their presence after the end of vitellogenesis is an accessory. However there is a possibility that the remaining material form some sort of appendages, that associated with the egg surface, may serve for eggs flutuation or fixation to a substrate, as verified in certain species (Anderson, 1966; Hart et al., 1984).

\section{REFERENCES}

ANDERSON, E., 1966, A study of the fibrillar appendages associated with the surface of eggs of the killifish, Fundulus heteroclitus. Anat. Rec., 154: 308-309.

ANDERSON, E., 1967, The formation of the primary envelope during oocyte differentiation in teleosts. J. Cell Biol., 35: $193-212$.

ANDERSON, E., 1974, Comparative aspects of the ultrastructure of the female gamete. Int. Rev. Cytol., 4(suppl.): $1-70$.

BEGOVAC, P. C. \& WALLACE, R. A., 1989, Major vitellins envelope proteins in piperfish oocytes originate within the follicle and are associated with the $\mathrm{Z}_{3}$ layer. J. Exp. Zool., 251: 56-73.

BRUSLÉ, S., 1980, Fine structure of early previtellogenic oocytes in Mugil (liza) auratis Risso, 1810 (Teleostei: Mugilidae). Cell Tissue Res., 207: 123-134.

BUSSON-MABILLOT, S., 1977, Un type particulier de sécretion exocrine: celui de 1'appareil adhésif de 1'veuf d'un poisson teléostéen. Biol. Cellulaire, 30: 233-244.

CHAUDRY, H. S., 1956, The origin and structure of the zona pellucida in the ovarian eggs of teleosts. Z. Zellforsch., 43: 478-485.

CRUZ-HÖFLING, M. A. \& CRUZ-LANDIM, C., 1990, The ultrastructure of the developmental stages of the oocytes of Astyanax bimaculatus (Teleostei: Characidae). Zool. Jb. Anat., 120: 1963-181.

CRUZ-HÖFLING, M. A. \& CRUZ-LANDIM, C., 1992, U1trastructural studies on the follicular epithelium during oocyte growth in the Amazonian fish, Crenicichla johanna (Teleostei: Cichlidae). Zool. Jb. Ant., 122: 1-15.

CRUZ-LANDIM, C. \& CRUZ-HÖFLING, M. A., 1979, Comportamento de nucléolos e mitocôndrios durante a ovogênese de peixes teleósteos de água doce. Acta Amazônica, 9: 723-728.
CRUZ-LANDIM, C., 1990, Aspectos ultra-estruturais das células produtoras de esteóides do ovário de Colossoma mitrei (Teleostei: Characidae). COLÓQUIO DA SOC. BRASIL. MICR. ELETR., 255-256.

CRUZ-LANDIM, C., SILVA DE MORAES, R. L. M. \& CRUZ-HÖFLING, M. A., 1987, Aspectos ultraestruturais das células foliculares de Crenicichla johanna (Teleostei: Cichlidae). AN. XI COLÓQUIO DA SOC. BRAS. MICR. ELETR., Caxambú, MG, p. 107.

DROLLER, M. J. \& ROTH, T. F., 1966, An electron microscope study of yolk formation during oogenesis in Lebistes reticulatus uppyi. Cell Biol., 28: 209-232.

DUMONT, J. N. \& BRUMMETT, A. R., 1980, The vitelline envelope, chorion and micropyle of Fundulus heteroclitus eggs. Gamete Res., 3: 25-44.

FLEGER, C., 1977, Electron microscopic studies on the development of the chorion of the viviparous teleost Dermogenys pusillus (Hemirhamphidae). Cell Trissue Res., 179: 255-270.

HART, N. H., PIETRI, R. \& DONOVAN, M., 1984, The structure of the chorion and associated surface filaments in Oryzias evidence for the presence of extracellular tubules. J. Exp. Zool., 230: 273-296.

HIROSE, K., 1972, The ultrastructure of the ovarian follicle of medaka (Oryzias latipes). Z. Zellforsch., 123: 316-329.

IWASAKI, Y., 1973, Histochemical detection of 3 hidroxysteroid dehydrogenase in the ovary of medaka, Oryzias latipes, during annual reproductive cycle. Hokkaido Univ. Bull. Fac. Fish., 23: 177-184.

KHOO, K. H., 1975, The corpus luteum of gold fish (Carassius auratus L.) and its functions. Can. J. Zool., 53: 1306-1323.

LAMBERT, J. G. D., 1970, The ovary of the guppy Poecilia reticulta. The granulosa cells as sites of steroid biosynthesis. Gen. Comp. Endocrinol., 15: 464-476.

LOPES, R. A., SANTOS, H. S. L., COSTA, J. R. V., PELIZARO, M. G. \& CASTAGNOLI, N., 1982, Histochemical study of oocyte zona radiata of the lambari Astyanax bimaculatus lacustris Linnaeus, 1758 (Osteichthyes: Characidae). Zool. Anz., 208: 265-268.

NICHOLLS, T. J. \& MAPLE, G., 1972, Ultrastructural observations on possible sites of steroid biosynthesis in the ovarian follicular epithelium of two species of cichlid fish, Cichlasoma nigrofasciatum and Haplochomie multicolor. Z. Zellforsh., 128: 317-335.

NORREVANG, A., 1968, Electron microscopic morphology of oogenesis. Intern. Rev. Cytol., 23: 113-186.

PEARSE, A. G. E., 1960, Histochemistry: Theoretical and Applied. J. \& A. Churchill Ltd., London, p. 998.

SHACKLEY, S. E. \& KING, P. E., 1977, Oogenesis in a marine teleost, Blennius pholis. L. Cell Tiss. Res., 105: 105128 . 
SHELTON, W. L., 1978, Fate of the follicular epithelium in Dorosoma petenense (Pisces: Clupeidae). Copeia, 2: 237-244.

TESORIERO, J. V., 1978, Formation of the chorion (Zona Pellucida) in the Teleost, Oryzias latipes. J. Ultr. Res., 64: 315-326.

WOURMS, J. P., 1976, Annual fish oogenesis. I. Differentiation of the mature oocyte and formation of the primary envelope. Devel. Biol., 50: 338-354.
WOURMS, J. P. \& SHELDON, H., 1976, Annual fish oogenesis. II. Formation of the secondary envelopes. Devel. Biol., 50: 355-366. 